\title{
Identification of the causal agents of crazy root disease on hydroponically cultivated cucumber plants in Poland
}

\author{
Michał Warabieda $(D)$ Artur Mikiciński $D$ - Marcin \\ Oleszczak • Joanna Puławska (D)
}

Accepted: 22 July 2021 / Published online: 12 August 2021

(C) The Author(s) 2021

\begin{abstract}
In April 2019, hydroponically cultivated cucumber plants with characteristic symptoms of crazy root disease were found in two different commercial production cucumber greenhouses in Poland. Due to excessive and inappropriate root growth, this disease led to a reduction in yield and deterioration of the general conditions of infected plants. Bacteria isolated from the roots were subjected to a morphological evaluation, as well as molecular, biochemical and pathogenicity tests. To identify the bacteria causing the disease, Agrobacterium-like colonies were subjected to PCR with primers complementary to the pathogenicityrelated genes located on the crazy root-inducing plasmid (Ri-plasmid): the virD2A + virD2E primers complementary to the virD2 gene and the rolBF + rolBR primers complementary to the $\mathrm{rolB}$ gene. The pathogenicity of the isolated strains was studied in sunflowers and cucumbers. Twelve strains positive for the Ri plasmid, as determined by PCR, and pathogenic to sunflowers were identified based on sequence analysis of the 16S rRNA and recA genes. One strain was classified as belonging to the genus Pararhizobium, three to Rhizobium, and eight to Agrobacterium biovar 1, with the highest similarity to genomospecies G3. The results of
\end{abstract}

M. Warabieda $(\bowtie) \cdot$ A. Mikiciński $\cdot$ J. Puławska

Department of Plant Protection, The National Institute of

Horticultural Research, ul. Konstytucji 3 Maja 1/3,

96-100 Skierniewice, Poland

e-mail: michal.warabieda@inhort.pl

M. Oleszczak

Intermag Sp. z o.o, Olkusz, Poland the analyses suggest that these strains may belong to a new, thus far, undescribed species. To confirm this hypothesis, further phylogenetic studies are required.

Keywords Ri-plasmid $\cdot$ Hairy root $\cdot$ Root mat . Detection · Phylogeny

\section{Introduction}

The occurrence of crazy root disease, also known as a root mat or hairy root, is responsible for significant economic losses, especially in hydroponic vegetable production. This disease infects dicotyledons and was first described as a soilborne disease in apples (Riker et al., 1930) at the beginning of the twentieth century. In recent years, crazy roots have been noted mainly in tomatoes and cucumbers but have also been found in melons and aubergines in the United Kingdom, France (Weller et al., 2000), New Zealand, Greece, Japan (Sawada \& Azegami, 2014), Russia (Ignatov et al., 2016) and Belgium (Bosmans et al., 2015, 2017).

Based on reports of crazy roots in different plant species, it is known that the bacteria causing this disease carry root-inducing plasmids (Ri-plasmids). Bacteria that cause this disease and belong to the genus Agrobacterium have been classified mainly as Agrobacterium bv 1 genomospecies: G1, G3, G7, G8, and G9 (Sawada \& Azegami, 2014; Bosmans et al., 2015, 2017; Ignatov et al., 2016). Among other species known to possess causal agents of crazy root disease, 
Rhizobium rhizogenes (formerly Agrobacterium biovar 2) and Allorhizobium vitis (formerly Agrobacterium vitis or Agrobacterium biovar 3) have also been reported, and both species are also known to be causal agents of crown gall disease (Weller et al., 2000).

Agrobacteria belong to the family Rhizobiaceae and naturally occur in soils. They can cause crazy root disease or crown gall disease in a variety of plant species or be non-pathogenic (Puławska, 2010; Bosmans et al., 2015). Crazy root-inducing (rhizogenic) strains are mainly acknowledged to cause losses in cucumber and tomato hydroponic production. Tumorigenic bacteria cause financial decreases in plant nurseries, such as fruit trees, roses (Rosa spp.), walnuts (Juglans spp.), almonds (Prunus dulcis), and grapevines (Vitis vinifera) (Campillo et al., 2012).

Interestingly, other $\alpha$-Proteobacteria, such as Ochrobactrum and Sinorhizobium, which also possess a Ri-plasmid, can cause symptoms of crazy root disease. Although a previous study showed that the pathogenicity tests of these bacteria were positive for the inoculation of cucumber cotyledons (Weller et al., 2004), their ability to cause disease symptoms was not observed in the whole-plant host test. This results was probably because not only genes located on the plasmid but also genes present on the bacterial chromosome are responsible for attachment to plant tissue and are involved in the transformation process and the further development of symptoms of crazy roots (Weller et al., 2005).

The characteristic trait of crazy root disease is uncontrolled, intensive and extended root proliferation. Anomalous roots are covered with numerous hairs, which are responsible for hindering the absorption of both nutrients and water (Nilsson \& Olsson, 1997). In addition, the symptoms of the disease can also include early flowering, wrinkled leaves, changes in apical dominance or a shortened internode length (Tepfer, 1984). The decreased vitality of such plants is also associated with greater susceptibility to secondary infections, which makes a cultivation more expensive.

The appearance of the symptoms of crazy root disease is closely associated with the transfer of a specific section, called T-DNA (transfer DNA), of the Riplasmid into the plant cell, its integration into host DNA and its subsequent expression. This process occurs in a similar manner to the phenomenon of the transfer and expression of a particular segment of the tumour-inducing plasmid (Ti plasmid) in tumorigenic Agrobacterium (Hooykaas \& Beijersbergen, 1994); however, in the case of the Ri plasmid, a different set of genes is located on T-DNA. pRi-derived T-DNA bears root oncogenic loci genes (rol genes), and the expression of these genes in plant cells is responsible for the induction of abnormal root development (Chilton et al., 1982). In general, the rol genes increase the sensitivity of plants to endogenous auxins - plant hormones that play a key role in the coordination of growth and development processes in plant life cycles (Shen et al., 1988). The precise function of the RolA protein has not been fully determined. However, the expression of the rolA gene is correlated with the reduction of certain hormone levels, such as ethylene, abscisic acid, auxin, gibberellin or cytokinin (Dehio et al., 1993). Expression of the rolB gene appears to be the main factor responsible for the formation of fast-growing, branched roots, which are characteristic of crazy root disease (Altamura, 2004). Moreover, high expression of rolB has been found in meristems within a vascular system (in the pericycle, xylem and phloem), indirectly influencing proliferation and differentiation of those cells (Altamura et al., 1991, 1994). The rolC gene (as well as $r o l B$ ) is considered a factor responsible for the appearance of changes in secondary metabolism (Shkryl et al., 2008). The expression of rolD is thought to be connected with an earlier entry into the generative growth phase, resulting in an increased number of flowering meristems and generative auxiliary buds (Mauro et al., 1996; Falasca et al., 2010). The structure of the Ri plasmid is not consistent in all bacterial strains. The parts of the Ri plasmid that are present in all isolates are the opine catabolism region and the origin of replication (ori), which are regions that are essential for the pathogenicity virulence region (vir) (Otten, 2018). These plasmids can be transferred to non-pathogenic agrobacteria or rhizobia, which explains how pathogenic populations can easily develop (Kerr \& Panagopoulos, 1977; Weller et al., 2004).

In April 2019, crazy root symptoms were observed in hydroponically cultivated cucumbers (Cucumis L.); abnormal roots grew across rockwool surfaces and within rockwool propagation cubes in greenhouses growing two cucumber producers in the neighbourhood of Kalisz and in two other greenhouses near Kraków, Poland (Supplementary Fig. S1). The roots of the obtained cucumbers were highly branched and covered with root hairs. The aim of our study was to determine the aetiology of the observed symptoms in cucumbers and to characterize their causal agent. 


\section{Materials and methods}

Sample collection

Samples of cucumber plants with crazy root symptoms were collected from two greenhouses located nearby Kalisz and next two located nearby Kraków. From each greenhouse, 1-2 diseased plants were collected. The cucumbers were in $\mathrm{BBCH}$ 71-72 stage (first fruits). Roots were washed in tap water and surface sterilized by wiping them with $70 \%$ ethanol. Bacteria were isolated from the inner tissue of hairy roots (2-3 samples per each cucumber plant) on King's B (King et al., 1954), $\mathrm{MG}+\mathrm{Te}$ (Mougel et al., 2001), 1A + 2E (Puławska \& Sobiczewski, 2005) media.

\section{Bacterial identification}

Bacterial colonies with a morphology resembling agrobacteria were preidentified using multiplex PCR with primers complementary to 23S rDNA (Puławska et al., 2006) to classify them at the biovar/species level. Additionally, DNA from the bacterial colonies was subjected to PCR with the primers virD2A + virD2E (Haas et al., 1995), which are complementary to the virD2 gene located on $\mathrm{Ti}$ and Ri plasmids for the detection of pathogenic isolates, and PCR amplification of the rolB gene with the primers rolBF (Bosmans et al., 2016) + rolBR (Weller \& Stead, 2002) was performed to identify strains able to induce hairy root disease.

\section{Pathogenicity testing}

The isolates preidentified as Agrobacterium/Rhizobium spp. were tested on sunflower seedlings according to Puławska and Sobiczewski (2005) to determine their pathogenicity. Briefly, 7-day-old sunflower seedlings were wounded with a sterile scalpel, and the wound was inoculated with the tested bacteria $\left(10^{8} \mathrm{cfu}\right)$. The inoculated seedlings were planted in soil in pots and grown in the greenhouse, temperature: $15,40{ }^{\circ} \mathrm{C}-$ $37,90{ }^{\circ} \mathrm{C}$; HR: $18,1 \%$ - $90 \%$. Plants were fertilized with multi-component fertilizer (Florovit, Inco, Poland) every week with dose recommended by the manufacturer and the presence of hairy roots was assessed after 30 days. Each bacterial strain was tested on four plants.

Cucumber plants Pacto F1 were propagated from seeds in propagation cubes (Skierniewice, Poland). Three weeks after sowing, the plants were inoculated with strains containing Ri plasmids (positive in rolB and virD PCRs) (Table 1) and pathogenic to sunflowers. Inoculation was performed by making an approximately $2 \mathrm{~cm}$ incision in the stem of each plant with a sterile scalpel. Bacteria from a single bacterial colony $\left(10^{8} \mathrm{cfu}\right)$ of the selected strain were directly applied to each wound, and then, the wound was carefully wrapped with parafilm. Control cucumber plants were wounded but not inoculated with bacteria. All the plants were grown in the same glasshouse room temperature: $14.00{ }^{\circ} \mathrm{C}-$ $31.14{ }^{\circ} \mathrm{C}$; HR $31 \%-91 \%$. The plants were fed with commercial fertilizer and were reviewed regularly as in test on sunflowers. Two months after inoculation, bacteria were isolated from plants that showed crazy root symptoms (Supplementary Fig. S1c) and were identified by PCR with the rolB primers to fulfil Koch's postulates.

\section{Biochemical tests}

Agrobacterium strains were subjected to analysis of the biochemical properties characteristic of the Agrobacterium genus: 3-ketolactose production, acid or alkali production from citrate and erythritol, growth and pigmentation in ferric ammonium citrate broth, oxidase reaction and activity in litmus milk (Moore et al., 2001).

Housekeeping gene sequencing and phylogenetic analyses

The 16S rRNA gene fragment of 12 selected strains (Table 1) was amplified with the primers $\mathrm{fD} 1$ and $\mathrm{rP} 2$ (Weisburg et al., 1991). The same primers were used for sequencing by the Genomed S.A. (Warsaw, Poland) commercial service. Identification of the nearest phylogenetic neighbours of the sequenced 16S rRNA was carried out using the EzTaxon database (http://www. eztaxon.org/) (Yoon et al., 2017). Because recA gene sequences are treated as a marker for the Agrobacterium and Rhizobium genera (De Lajudie et al., 2019) and because a complete database of $r e c A$ sequences for type strains of all species in these genera has been established, we amplified and sequenced the fragments of this gene from all the tested isolates with the primers ArecAF and ArecR according to the originally described conditions (Puławska et al., 2016b). Two recA maximum likelihood phylogenetic trees were constructed with MEGA X (Kumar et al., 2018) (Fig. 1, 


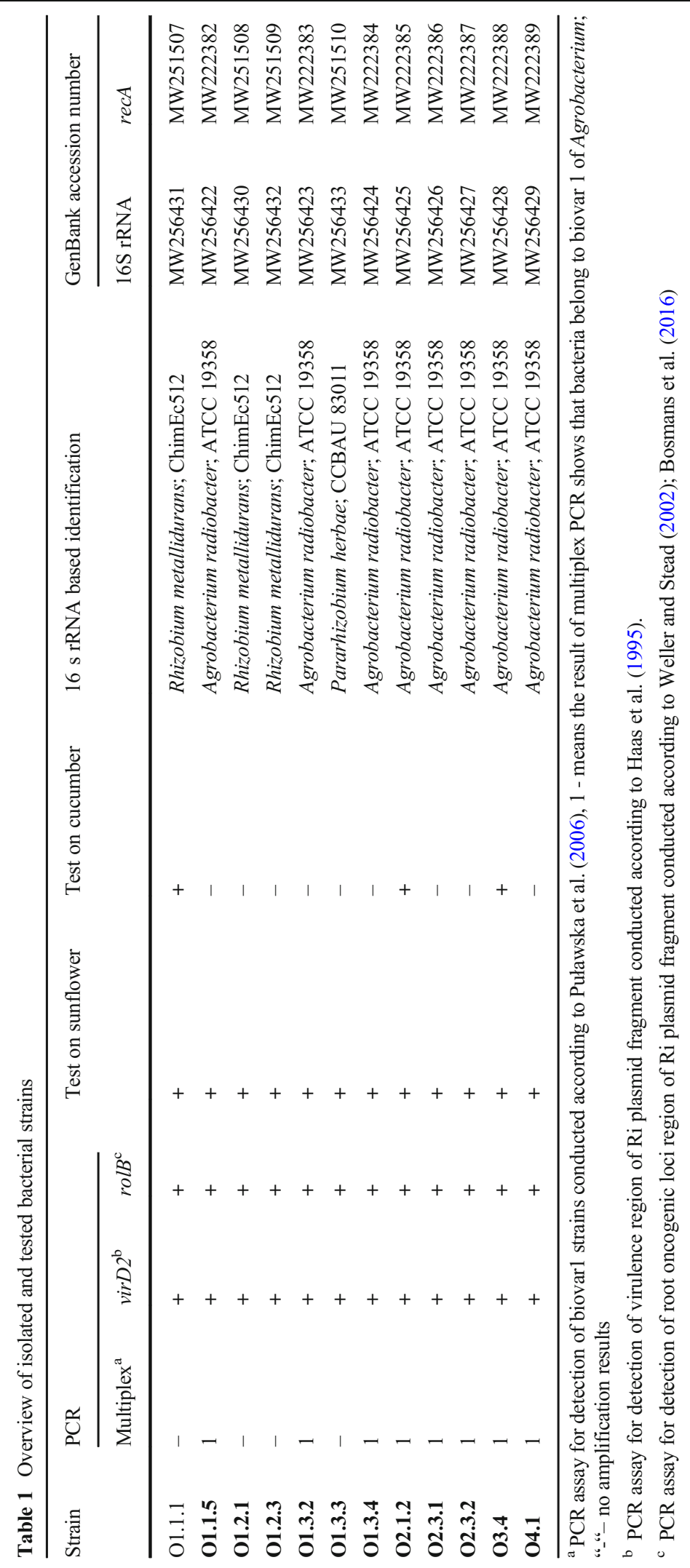


Supplementary Fig. S2). Dendrograms were constructed using the general time reversible evolutionary model with a gamma distribution and by assuming that a certain fraction of sites were evolutionarily invariable $(\mathrm{G}+\mathrm{I})$ as this was found to be the best substitution model (Kumar et al., 2018). One dendrogram with all the members of the genus Agrobacterium for cucumber strains belonging to Agrobacterium and a second dendrogram with type strains of all the validly published species of Rhizobium and Pararhizobium for strains classified as belonging to these genera based on the $16 \mathrm{~S}$ rRNA analysis were constructed. The significance of the internal branches of the phylogenetic trees was estimated with 500 bootstrap replicates.

\section{Results and discussion}

Out of the 51 strains isolated from the tested cucumbers, 12 that were preidentified as Agrobacterium/Rhizobium were pathogenic when tested on sunflowers, and after re-isolation, the identity of the inoculated bacteria was confirmed by colony morphology and PCR with primers complementary to the rolB gene. All 12 strains causing abnormal root growth in the area of infection in sunflower seedlings were positive according to PCR with the virD and $\operatorname{rolB}$ gene primers, suggesting that these strains possessed Ri plasmids.

We used sunflower seedlings to test the pathogenicity of the bacteria because this plant species is very susceptible to a wide range of Agrobacterium and

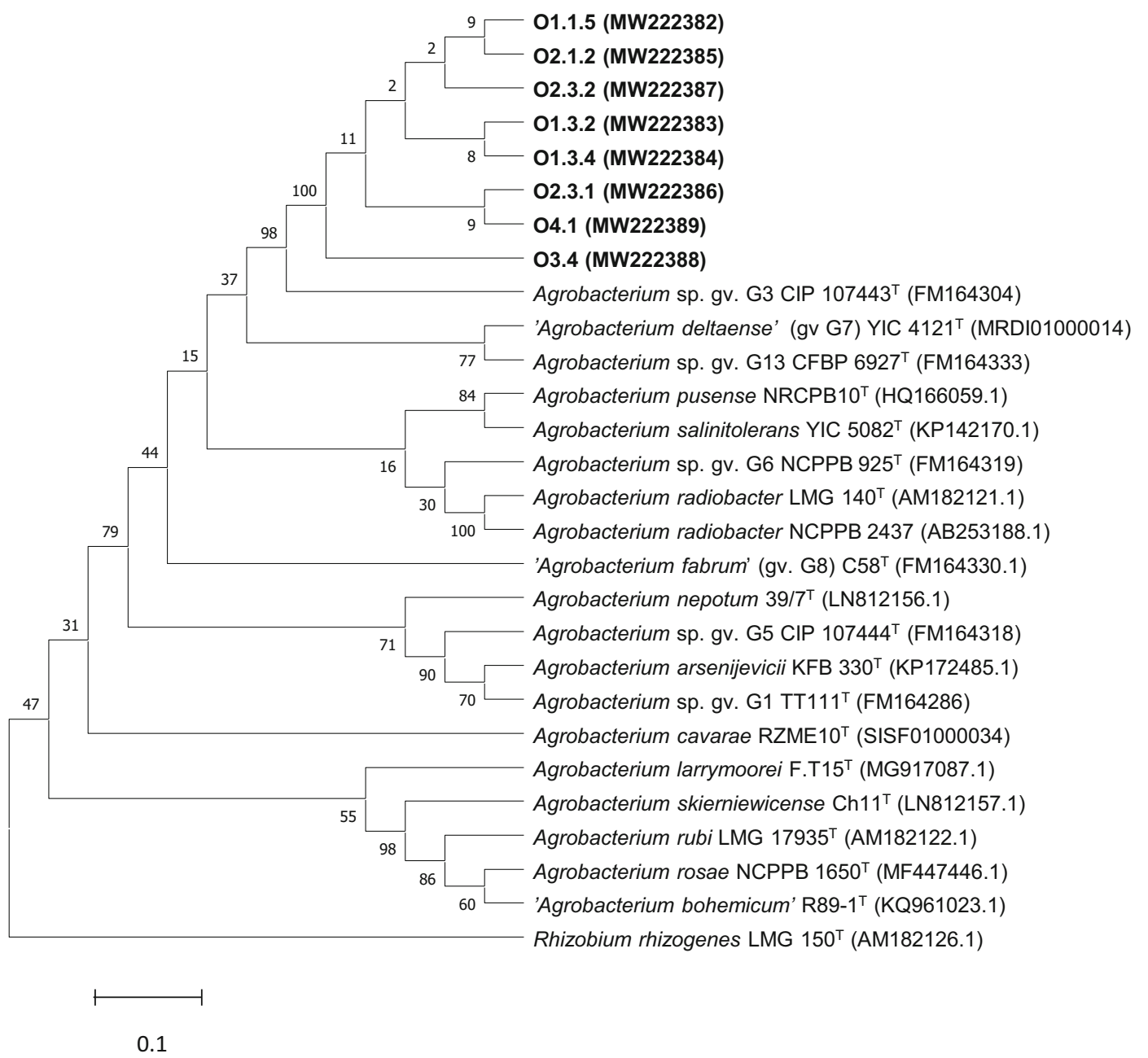

Fig. 1 Maximum likelihood phylogenetic tree obtained from the sequence of chromosomal housekeeping gene $r e c A$ for type strains of all Agrobacterium species and the strains from cucumber characterized in this study. As an outgroup, the sequence of $r e c A$ gene Rhizobium rhizogenes $\mathrm{LMG} 150^{\mathrm{T}}$ was used to root the tree 
Rhizobium strains, both tumorigenic and rhizogenic. The observed results suggested that the strains differed in terms of their virulence level because some of them produced more intensive symptoms than others.

Out of the 12 pathogenic on sunflower strains, only three were pathogenic toward cucumbers (Table 1). The infected cucumber plants developed numerous, highly branched roots, mainly from the infected wound site. The newly formed roots overgrew the old root ball and reached its surface. The factor that may influence the efficiency of transformation, and thus the appearance of disease symptoms, is the concentration of the bacterial suspension used in the experiment (Paz et al., 2006). However, in the case of our experiment, it was unlikely that the concentration of the bacterial suspension had an effect because we used a large number of bacterial cells to inoculate one plant. Nevertheless, there are examples for which the optimal concentration of the bacterial suspension depends on the plant species or cultivar and the bacterial strain (Hiei et al., 1997; Giovannini, 2006).

The ability of infection of a particular plant species or even cultivar by the individual bacterial strain may depend on the interactions between host plant cells and the strain and on the interaction between the plasmid and chromosomal machinery within the strain (Gelvin, 2003; Tiwari et al., 2007). For example, the Ti plasmid pTiBo542, in its natural host strain Agrobacterium sp. Bo542, shows limited tumorigenic potential when tested on different leguminous plant species. However, when placed in the strain C58 chromosomal background, pTiBo542 directs strong virulence toward soybeans and other legumes (Gelvin, 2003). The mechanism of this phenomenon is not well recognized, however some potential reasons like stress-induced changes in lipopolysaccharide (LPS) components were found as resulting in impaired virulence of rhizogenic and tumorigenic strains (Arafat et al., 2009).

Identification of the nearest phylogenetic neighbours based on the sequence of 16S rRNA showed that 8 strains belonged to Agrobacterium, 3 strains belonged to Rhizobium and 1 strain belonged to Pararhizobium (Table 1).

The phylogenetic analysis of $r e c A$ allowed us to conduct a more precise classification of bacteria. The Agrobacterium strains showed the highest similarity to genomospecies G3 (Fig. 1); however, they created a separate phylogenetic lineage with a high bootstrap value, which suggests that they could belong to a new genomospecies. To confirm this hypothesis, further studies with genomic sequencing should be performed. Bacteria belonging to $\mathrm{G} 3$, to our knowledge, have not been reported to cause crown gall but have been reported to be the causal agents of crazy root disease (Bosmans et al., 2015, 2017).

Due to allelic diversity, several genomospecies within biovar 1 (also called the Agrobacterium tumefaciens species complex) were distinguished based on their recA gene sequences, including genomospecies G3 (Costechareyre et al., 2010). Technological progress in the field of genomic sequencing has increased the importance of in silico techniques (Auch et al., 2010; Colston et al., 2014). On this basis, several genomic species with genomovar numbering were distinguished from the Agrobacterium tumefaciens species complex, and some of them were validly described as species, e.g., G2 as Agrobacterium pusense (Panday et al., 2011; Mousavi et al., 2015) or G14 as Agrobacterium nepotum (Puławska et al., 2012; Mousavi et al., 2015). To simplify the diversity problem of genetically separated species, the concept of assigning them to an ecological species has been developed (Lassalle et al., 2011). However, the strains assigned to Agrobacterium G3 have been isolated from different and independent environments, which can be problematic for scientists to acknowledge them as a single ecological species (Popoff et al., 1970; Bhullar et al., 2012; Bai et al., 2015; Jones et al., 2016).

The strains belonging to the Agrobacterium genus possessed characteristic biochemical features: they possessed the ability to produce 3-ketolactose from $\alpha$ lactose and were oxidase positive. In litmus milk, they performed alkaline reactions; they grew in ferric ammonium citrate broth with pigmentation; they did not utilize erythritol, but they differed in terms of their citrate utilization. Three strains (O1.1.5, O2.3.1, O3.4) produced alkali, and 5 strains (O1.3.2, O1.3.4, O2.1.2, $\mathrm{O} 2.3 .2, \mathrm{O} 4.1)$ produced acid from citrate.

Three other pathogenic strains, O1.1.1, O1.2.1 and O1.2.3, belonging to the genus Rhizobium based on the $r e c A$ analysis, created the phylogenetic lineage closest to Rhizobium metallidurans, while strain O1.3.3 was located near Pararhizobium species (Supplementary Fig. S2); however, for the strains in these two phylogenetic lineages, precise classification was not possible without whole genome sequencing. Neither $R$. metallidurans nor Pararhizobium strains have been previously reported as causing crazy root or crown gall 
disease, although $P$. polonicum was initially isolated from the galls of fruit trees (Puławska et al., 2016a). Bacteria classified as $R$. metallidurans were first identified in a zinc mining site. These bacteria are described as being tolerant to high concentrations of heavy metals, such as zinc and cadmium (Grison et al., 2015).

\section{Conclusions}

Our study reports, for the first time in Poland, the results of the identification and characterization of bacteria causing crazy root disease in cucumbers grown hydroponically. We observed that the bacterial strains isolated from diseased cucumbers were characterized by different degrees of pathogenicity and virulence in both sunflowers and cucumbers.

The results showed that new bacterial species involved in the disease might belong to new, hitherto undescribed species. Further studies including additional phylogenetic markers and whole genome sequencing should be performed to determine the actual taxonomic position of these species.

Supplementary Information The online version contains supplementary material available at https://doi.org/10.1007/s10658021-02340-6.

Acknowledgements The research work was carried out in the frame of statutory grant number 2.1.5."New bacterial diseases of horticultural plants in Poland - identification, characterization and detection of their causal agents" funded by Ministry of Science and Higher Education.

Code availability Not applicable.

Author contribution MW isolated bacteria, identified them using molecular biology tools, performed phylogenetic and biochemical features analyses and pathogenicity tests on cucumbers; AM performed pathogenicity tests on sunflowers; MO monitored the greenhouses, found and delivered diseased plants; JP is the author of the conception of the study and its design. The manuscript was written by MW and JP. All authors contributed to manuscript revision, read and approved the submitted version.

Funding The research work was carried out in the frame of statutory grant number 2.1.5."New bacterial diseases of horticultural plants in Poland - identification, characterization and detection of their causal agents" funded by Ministry of Science and Higher Education.
Data availability The gene sequences generated and analysed during the current study are available under accession numbers: MW251507-10; MW222382-9; MW256422-33.

\section{Declarations}

Authors declare that the manuscript is entirely original and have not been, and will not be, published elsewhere if accepted for publishing in EJPP. The content and authorship of the submitted manuscript has been approved by all authors, and all prevailing local, national and international regulations and conventions, and normal scientific ethical practices have been respected. Authors declare no competing interests

Conflicts of interest/competing interests The Authors declare no conflict of interest.

Open Access This article is licensed under a Creative Commons Attribution 4.0 International License, which permits use, sharing, adaptation, distribution and reproduction in any medium or format, as long as you give appropriate credit to the original author(s) and the source, provide a link to the Creative Commons licence, and indicate if changes were made. The images or other third party material in this article are included in the article's Creative Commons licence, unless indicated otherwise in a credit line to the material. If material is not included in the article's Creative Commons licence and your intended use is not permitted by statutory regulation or exceeds the permitted use, you will need to obtain permission directly from the copyright holder. To view a copy of this licence, visit http://creativecommons.org/licenses/by/4.0/.

\section{References}

Altamura, M. M. (2004). Agrobacterium rhizogenes rolB and rolD genes: Regulation and involvement in plant development. Plant Cell, Tissue and Organ Culture, 77, 89-101. https://doi.org/10.1023/B:TICU.0000016609.22655.33.

Altamura, M. M., Archilletti, T., Capone, I., \& Costantino, P. (1991). Histological analysis of the expression of agrobacterium rhizogenes rolB-GUS gene fusions in transgenic tobacco. New Phytologist, 118, 69-78. https://doi. org/10.1111/j.1469-8137.1991.tb00566.x.

Altamura, M. M., Capitani, F., Gazza, L., Capone, I., \& Costantino, P. (1994). The plant oncogene rolB stimulates the formation of flower and root meristemoids in tobacco thin cell layers. New Phytologist, 126, 283-293. https://doi. org/10.1111/j.1469-8137.1994.tb03947.x.

Arafat, H. H., Tanaka, K., Sawada, H., \& Suzuki, K. (2009). Variation of lipopolysaccharide among the three major agrobacterium species and the effect of environmental stress on the lipopolysaccharide profile. Plant Pathology Journal, 8, 1-8. https://doi.org/10.3923/ppj.2009.1.8.

Auch, A. F., von Jan, M., Klenk, H. P., \& Göker, M. (2010). Digital DNA-DNA hybridization for microbial species 
delineation by means of genome-to-genome sequence comparison. Standards in Genomic Sciences, 2, 117-134. https://doi.org/10.4056/sigs.531120.

Bai, Y., Müller, D. B., Srinivas, G., Garrido-Oter, R., Potthoff, E., Rott, M., Dombrowski, N., Münch, P. C., Spaepen, S., Remus-Emsermann, M., Hüttel, B., McHardy, A. C., Vorholt, J. A., \& Schulze-Lefert, P. (2015). Functional overlap of the Arabidopsis leaf and root microbiota. Nature, 528, 364-369. https://doi.org/10.1038/nature16192.

Bhullar, K., Waglechner, N., Pawlowski, A., Koteva, K., Banks, E. D., Johnston, M. D., Barton, H. A., \& Wright, G. D. (2012). Antibiotic resistance is prevalent in an isolated cave microbiome. PLoS One, 7(4), e34953. https://doi. org/10.1371/journal.pone.0034953.

Bosmans, L., Moerkens, R., Wittemans, L., De Mot, R., Rediers, H., \& Lievens, B. (2017). Rhizogenic agrobacteria in hydroponic crops: Epidemics, diagnostics and control. Plant Pathology, 66, 1043-1053. https://doi.org/10.1111 /ppa.12687.

Bosmans, L., Paeleman, A., Moerkens, R., Wittemans, L., Van Calenberge, B., Van Kerckhove, S., et al. (2016). Development of a qPCR assay for detection and quantification of rhizogenic agrobacterium biovar 1 strains. European Journal of Plant Pathology, 145, 719-730. https://doi. org/10.1007/s10658-016-0861-6.

Bosmans, L., Lvarez-Prez, S., Moerkens, R., Wittemans, L., Van Calenberge, B., Van Kerckhove, S., et al. (2015). Assessment of the genetic and phenotypic diversity among rhizogenic agrobacterium biovar 1 strains infecting solanaceous and cucurbit crops. FEMS Microbiology Ecology, 91(8). https://doi.org/10.1093/femsec/fiv081.

Campillo, T., Lavire, C., Shams, M., Pothier, J. F., \& Puławska, J. (2012). Detection and identification methods and new tests as developed and used in the framework of cost 873 for bacteria pathogenic to stone fruits and nuts. Journal of Plant Pathology, 94, 135-146.

Chilton, M. D., Tepfer, D. A., Petit, A., David, C., Casse Delbart, F., \& Tempé, J. (1982). Agrobacterium rhizogenes inserts TDNA into the genomes of the host plant root cells. Nature, 295, 432-434. https://doi.org/10.1038/295432a0.

Colston, S. M., Fullmer, M. S., Beka, L., Lamy, B., Peter Gogarten, J., \& Graf, J. (2014). Bioinformatic genome comparisons for taxonomic and phylogenetic assignments using aeromonas as a test case. $\mathrm{mBio}, 5$. https://doi.org/10.1128 /mBio.02136-14.

Costechareyre, D., Rhouma, A., Lavire, C., Portier, P., Chapulliot, D., Bertolla, F., Boubaker, A., Dessaux, Y., \& Nesme, X. (2010). Rapid and efficient identification of agrobacterium species by recA allele analysis. Microbial Ecology, 60, 862872. https://doi.org/10.1007/s00248-010-9685-7.

De Lajudie, P. M., Andrews, M., Ardley, J., Eardly, B., JumasBilak, E., Kuzmanović, N., et al. (2019). Minimal standards for the description of new genera and species of rhizobia and agrobacteria. International Journal of Systematic and Evolutionary Microbiology, 69(7), 1852-1863. https://doi. org/10.1099/ijsem.0.003426.

Dehio, C., Grossmann, K., Schell, J., \& Schmülling, T. (1993). Phenotype and hormonal status of transgenic tobacco plants overexpressing the rolA gene of agrobacterium rhizogenes T-DNA. Plant Molecular Biology, 23, 1199-1210. https://doi.org/10.1007/BF00042353.
Falasca, G., Altamura, M. M., D’Angeli, S., Zaghi, D., Costantino, P., \& Mauro, M. L. (2010). The rolD oncogene promotes axillary bud and adventitious root meristems in Arabidopsis. Plant Physiology and Biochemistry, 48(9), 797-804. https://doi.org/10.1016/j.plaphy.2010.06.002.

Gelvin, S. B. (2003). Agrobacterium-mediated plant transformation: The biology behind the "gene-jockeying" tool. Microbiology and Molecular Biology Reviews, 67, 16-37. https://doi.org/10.1128/mmbr.67.1.16-37.2003.

Giovannini, A. (2006). Tissue culture, cell culture and genetic transformation by wild type agrobacterium rhizogenes in Mediterranean Helichrysum. In J. A. Teixeira da Silva (Eds.), Floriculture, ornamental and plant biotechnology: Advances and topical issues, volume II (pp. 222-226). Global Science Books, Ltd.

Grison, C. M., Jackson, S., Merlot, S., Dobson, A., \& Grison, C. (2015). Rhizobium metallidurans sp. nov., a symbiotic heavy metal resistant bacterium isolated from the Anthyllis vulneraria Zn-hyperaccumulator. International Journal of Systematic and Evolutionary Microbiology, 65, 1525-1530. https://doi.org/10.1099/ijs.0.000130.

Haas, J. H., Moore, L. W., Ream, W., \& Manulis, S. (1995). Universal PCR primers for detection of phytopathogenic agrobacterium strains. Applied and Environmental Microbiology, 61, 2879-2884. https://doi.org/10.1128 /aem.61.8.2879-2884.1995.

Hiei, Y., Komari, T., \& Kubo, T. (1997). Transformation of rice mediated by Agrabacterium tumefaciens. Plant Molecular Biology, 35, 205-218. https://doi.org/10.1023 /a:1005847615493.

Hooykaas, P. J. J., \& Beijersbergen, A. G. M. (1994). The virulence system of agrobacterium tumefaciens. Annual Review of Phytopathology, 32, 157-179. https://doi.org/10.1146 /annurev.py.32.090194.001105.

Ignatov, A. N., Khodykina, M. V., Vinogradova, S. V., Polityko, V. A., Pluschikov, V. G., \& Kornev, K. P. (2016). First report of rhizogenic strains of agrobacterium radiobacter biovar 1 causing root mat of cucumber and tomato in Russia. Plant Disease, 100, 1493-1493. https://doi.org/10.1094/PDIS-1115-1382-PDN.

Jones, K. J., Moore, K., Sambles, C., Love, J., Studholme, D. J., \& Aves, S. J. (2016). Draft genome sequences of Achromobacter piechaudii GCS2, agrobacterium sp. strain SUL3, microbacterium sp. strain GCS4, Shinella sp. strain GWS1, and Shinella sp. strain SUS2 isolated from consortium with the hydrocarbon-producing alga Botryococcus brauni. Genome announcements, 4. https://doi.org/10.1128 /genomeA.01527-15, 4.

Kerr, A., \& Panagopoulos, C. G. (1977). Biotypes of agrobacterium radiobacter var. tumefaciens and their biological control. Journal of Phytopathology, 90, 172-179. https://doi.org/10.1111/j.1439-0434.1977.tb03233.x.

King, E. O., Ward, M. K., \& Raney, D. E. (1954). Two simple media for the demonstration of pyocyanin and fluorescin. The Journal of Laboratory and Clinical Medicine, 44(2), 301-307. https:/doi. org/10.5555/uri:pii:002221435490222X.

Kumar, S., Stecher, G., Li, M., Knyaz, C., \& Tamura, K. (2018). MEGA X: Molecular evolutionary genetics analysis across computing platforms. Molecular Biology and Evolution, 35(6), 1547-1549. https://doi.org/10.1093/molbev/msy096. 
Lassalle, F., Campillo, T., Vial, L., Baude, J., Costechareyre, D., Chapulliot, D., Shams, M., Abrouk, D., Lavire, C., OgerDesfeux, C., Hommais, F., Guéguen, L., Daubin, V., Muller, D., \& Nesme, X. (2011). Genomic species are ecological species as revealed by comparative genomics in agrobacterium tumefaciens. Genome Biology and Evolution, 3, 762-781. https://doi.org/10.1093/gbe/evr070.

Mauro, M. L., Trovato, M., De Paolis, A., Gallelli, A., Costantino, P., \& Altamura, M. M. (1996). The plant oncogene rolD stimulates flowering in transgenic tobacco plants. Developmental Biology, 180(2), 693-700. https://doi. org/10.1006/dbio.1996.0338.

Moore, L. W., Bouzar, H., \& Burr, T. (2001). Agrobacterium. In N. W. Schaad (Eds.), laboratory guide for identification of plant pathogenic Bacteria (3rd ed., pp. 17-35). APS Press, St Paul, MN,

Mougel, C., Cournoyer, B., \& Nesme, X. (2001). Novel telluriteamended media and specific chromosomal and ti plasmid probes for direct analysis of soil populations of agrobacterium biovars 1 and 2. Applied and Environmental Microbiology, 67, 65-74. https://doi.org/10.1128 /AEM.67.1.65-74.2001.

Mousavi, S. A., Willems, A., Nesme, X., de Lajudie, P., \& Lindström, K. (2015). Revised phylogeny of Rhizobiaceae: Proposal of the delineation of Pararhizobium gen. Nov., and 13 new species combinations. Systematic and Applied Microbiology, 38(2), 84-90. https://doi.org/10.1016/j. syapm.2014.12.003.

Nilsson, O., \& Olsson, O. (1997). Getting to the root: The role of the agrobacterium rhizogenes rol genes in the formation of hairy roots. Physiologia Plantarum, 100, 463-473. https://doi.org/10.1034/j.1399-3054.1997.1000307.x.

Otten, L. (2018). The agrobacterium phenotypic plasticity (Plast) genes. In current topics in microbiology and immunology (Vol. 418, pp. 375-419). Springer Verlag. https://doi. org/10.1007/82_2018_93.

Panday, D., Schumann, P., \& Das, S. K. (2011). Rhizobium pusense sp. nov., isolated from the rhizosphere of chickpea (Cicer arietinum L.). International Journal of Systematic and Evolutionary Microbiology, 61, 2632-2639. https://doi. org/10.1099/ijs.0.028407-0.

Paz, M. M., Martinez, J. C., Kalvig, A. B., Fonger, T. M., \& Wang, K. (2006). Improved cotyledonary node method using an alternative explant derived from mature seed for efficient agrobacterium-mediated soybean transformation. Plant Cell Reports, 25, 206-213. https://doi.org/10.1007/s00299-0050048-7.

Popoff, M. Y., Kersters, K., Kiredjian, M., Miras, I., \& Coynault, C. (1970). Taxonomic position of agrobacterium strains of hospital origin. Annales de Microbiologie, 135, 427-442.

Puławska, J. (2010). Crown gall of stone fruits and nuts, economic significance and diversity of its causal agents: Tumorigenic agrobacterium spp. Journal of Plant Pathology, 92, 87-98. https://doi.org/10.4454/jpp.v92i1sup.2510.

Puławska, J., \& Sobiczewski, P. (2005). Development of a seminested PCR based method for sensitive detection of tumorigenic agrobacterium in soil. Journal of Applied Microbiology, 98, 710-721. https://doi.org/10.1111/j.13652672.2004.02503.x.

Puławska, J., Warabieda, W., \& Ismail, E. (2016b). Identification and characterization of bacteria isolated from crown galls on stone fruits in Poland. Plant Pathology, 65, 1034-1043. https://doi.org/10.1111/ppa.12482.

Puławska, J., Kuzmanović, N., Willems, A., \& Pothier, J. F. (2016a). Pararhizobium polonicum sp. nov. isolated from tumors on stone fruit rootstocks. Systematic and Applied Microbiology, 39(3), 164-169. https://doi.org/10.1016/j. syapm.2016.03.002.

Puławska, J., Willems, A., De Meyer, S. E., \& Süle, S. (2012). Rhizobium nepotum sp. nov. isolated from tumors on different plant species. Systematic and Applied Microbiology, 35(4), 215-220. https://doi.org/10.1016/j. syapm.2012.03.001.

Puławska, J., Willems, A., \& Sobiczewski, P. (2006). Rapid and specific identification of four agrobacterium species and biovars using multiplex PCR. Systematic and Applied Microbiology, 29(6), 470-479. https://doi.org/10.1016/j. syapm.2005.11.002.

Riker, A. J., Banfield, W. M., Wright, W. H., Keitt, G. W., \& Sagen, H. E. (1930). Studies on infectious hairy root of nursery apple trees. Journal of Agricultural Research, 41, 507-540.

Sawada, H., \& Azegami, K. (2014). First report of root mat (hairy root) of tomato (Lycopersicon esculentum) caused by rhizobium radiobacter harboring cucumopine $\mathrm{Ri}$ plasmid in Japan. Japanese Journal of Phytopathology, 80, 98-114. https://doi.org/10.3186/jjphytopath.80.98.

Shen, W. H., Petit, A., Guern, J., \& Tempe, J. (1988). Hairy roots are more sensitive to auxin than normal roots. Proceedings of the National Academy of Sciences of the United States of America, 85, 3417-3421. https://doi.org/10.1073 /pnas.85.10.3417.

Shkryl, Y. N., Veremeichik, G. N., Bulgakov, V. P., Tchernoded, G. K., Mischenko, N. P., Fedoreyev, S. A., \& Zhuravlev, Y. N. (2008). Individual and combined effects of the rolA, $B$, and $C$ genes on anthraquinone production in Rubia cordifolia transformed calli. Biotechnology and Bioengineering, 100, 118-125. https://doi.org/10.1002/bit.21727.

Tepfer, D. (1984). Transformation of several species of higher plants by agrobacterium rhizogenes: Sexual transmission of the transformed genotype and phenotype. Cell, 37, 959-967. https://doi.org/10.1016/0092-8674(84)90430-6.

Tiwari, R. K., Trivedi, M., Guang, Z. C., Guo, G. Q., \& Zheng, G. C. (2007). Genetic transformation of Gentiana macrophylla with agrobacterium rhizogenes: Growth and production of secoiridoid glucoside gentiopicroside in transformed hairy root cultures. Plant Cell Reports, 26, 199-210. https://doi. org/10.1007/s00299-006-0236-0.

Weisburg, W. G., Barns, S. M., Pelletier, D. A., \& Lane, D. J. (1991). 16S ribosomal DNA amplification for phylogenetic study. Journal of Bacteriology, 173, 697-703. https://doi. org/10.1128/jb.173.2.697-703.1991.

Weller, S. A., \& Stead, D. E. (2002). Detection of root mat associated agrobacterium strains from plant material and other sample types by post-enrichment TaqMan PCR. Journal of Applied Microbiology, 92, 118-126. https://doi. org/10.1046/j.1365-2672.2002.01506.x.

Weller, S. A., Stead, D. E., O’Neill, T. M., \& Morley, P. S. (2000). Root mat of tomato caused by rhizogenic strains of agrobacterium biovar 1 in the UK. Plant Pathology, 49, 799. https://doi.org/10.1046/j.1365-3059.2000.00502.x. 
Weller, S. A., Stead, D. E., \& Young, J. P. W. (2004). Acquisition of an Agrobacterium Ri plasmid and pathogenicity by other $\alpha$-Proteobacteria in cucumber and tomato crops affected by root mat. Applied and Environmental Microbiology, 70(5), 2779-2785. https://doi.org/10.1128/AEM.70.5.27792785.2004 .

Weller, S. A., Stead, D. E., \& Young, J. P. W. (2005). Induction of root-mat symptoms on cucumber plants by rhizobium, but not by Ochrobactrum or Sinorhizobium, harbouring a cucumopine Ri plasmid. Plant Pathology, 54(6), 799-805. https://doi.org/10.1111/j.1365-3059.2005.01283.x.

Yoon, S. H., Ha, S. M., Kwon, S., Lim, J., Kim, Y., Seo, H., \& Chun, J. (2017). Introducing EzBioCloud: A taxonomically united database of 16S rRNA gene sequences and wholegenome assemblies. International Journal of Systematic and Evolutionary Microbiology, 67, 1613-1617. https://doi. org/10.1099/ijsem.0.001755. 